\title{
Bronchial symptoms and respiratory function in workers exposed to methylmethacrylate
}

\author{
T Marez, J L Edmé, C Boulenguez, P Shirali, J M Haguenoer
}

\begin{abstract}
This study aimed to investigate the pulmonary effects of methylmethacrylate (MMA) in a group of occupationally exposed workers. In the exposed group $20 \%$ had chronic cough compared with $1 \%$ in controls. Spirometric values at the beginning of the workshift were similar in both groups, but a mild airways obstruction appeared during the workshift. The maximum expiratory flow when $50 \%$ of the forced vital capacity remained to be exhaled $\left(M E F_{50}\right)$ and the ratio of $M E F_{50}$ to maximal expiratory flow (MEF $\left.{ }_{50} / \mathrm{MEF}\right)$ decreased significantly during the workshift among exposed workers $v$ controls $(p=0.04$ and 0.01 respectively). Results remained unaffected after adjustment for smoking. Exposure to MMA seems to be responsible for a mild airways obstruction but further study on a larger population would be useful.
\end{abstract}

(British Fournal of Industrial Medicine 1993;50:894-897)

Monomeric methylmethacrylate (MMA) has widespread use in the manufacture of acrylic resins. It is a component of paints and laquers. Polymers produced from MMA are widely used in various applications-for example, in the automobile, furniture, and construction industries and in orthopaedics and dentistry. Available data on the biological effects and toxicity of MMA have become voluminous and MMA has been generally regarded as an innocuous substance. Because of its great irritant power, however, exposure to MMA has resulted in respiratory disorders. Many experi-

Laboratoire de toxicologie, Institut de Médecine du travail-Faculté de Médecine 1, place de Verdun59045 Lille, Cédex, France

T Marez, P Shirali, J M Haguenoer

Laboratoire de Médecine du travail, Faculté de Médecine, Lille II, France

J L Edmé, C Boulenguez mental studies have shown alterations of the respiratory system of animals exposed to MMA. Thus hypocapnia, hypercapnia, acidosis, ${ }^{1}$ pulmonary oedema, ${ }^{2}$ haemorrhage, congestion, and necrosis, ${ }^{34}$ and Cheyne Stokes dyspnoea, ${ }^{5}$ have been described. In humans, functional disorders such as cough, sore throat, respiratory irritation, ${ }^{6}$ and occupational asthma ${ }^{7}$ have been noted. A recent study has shown a twofold higher prevalence of respiratory obstruction among workers exposed to MMA and styrene than among controls. ${ }^{8}$ The aim of the present study was to assess the effects of MMA on the lung function of workers occupationally exposed exclusively to the monomer. For this purpose, we carried out a study including a questionnaire and a maximum expiratory flow volume curve (MEFV) among exposed workers and controls.

\section{Materials and methods}

The study included a questionnaire, spirography, and an evaluation of the atmospheric concentration of MMA.

\section{ATMOSPHERIC MONITORING}

Atmospheric concentrations of MMA were evaluated by passive sampling on activated charcoal (badge 3M). After desorption in carbon disulphide MMA was analysed by direct injection into a gas chromatograph equipped with a flame ionisation detector. Atmospheric concentrations of MMA (ppm) were calculated from a formula given by the manufacturer. Monitoring was conducted in each workshop when production was running normally. The monitoring time was eight hours.

\section{QUESTIONNAIRE}

Smoking history and information on the presence of respiratory symptoms were gathered by a modified British Medical Research Council questionnaire. ${ }^{9}$ It included questions about present and past smoking habits. Non-smokers were persons who have never smoked. Smokers were persons who smoked cigarettes at the time of the interview. Exsmokers were those who once smoked cigarettes 
but who had not smoked for at least two years. From current and ex-smokers, the number of cigarettes smoked daily was ascertained and the pack-years of cigarettes smoked (pack-year = number of cigarettes smoked per day $\times$ number of years smoked /20) were calculated. Chronic bronchitis was defined as cough and phlegm production on most days for at least three months a year for two consecutive years or more. Asthma was defined as a positive answer to the question "Have you ever had bronchial asthma?"

\section{SPIROMETRY}

Maximum expiratory flow volume (MEFV) curves were obtained by the same well trained operator with the same FUKUDA Spiroanalyzer ST-200. Each period of measurement was preceded and followed by calibration with a 31 syringe. After being instructed in the procedure for measurement of forced vital capacity (FVC), subjects performed the test in a standing position without a nose clip. To insure that emphasis was put on both the completeness and the speed of the manoeuvre criteria used to choose the best curve were stricter than recommended by the American Thoracic Society. ${ }^{1011}$ To consider the test as valid, in less than six attempts, three acceptable expirations of which the sum of FVC + forced expiratory volume in one second $\left(\mathrm{FEV}_{1}\right)$ did not differ by more than $5 \%$ from each other had to be obtained. All variables were then recorded from the curve with the greatest sum of FVC $+\mathrm{FEV}_{1}$, unless the corresponding maximal expiratory flow (MEF) was lower by more than $10 \%$ of the best one performed by the subject. In that case the MEFV curve was withdrawn from the survey. Standard lung function variables included FVC, $\mathrm{FEV}_{1}, \mathrm{FEV}_{1} / \mathrm{FVC}, \mathrm{MEF}$, and maximal expiratory flows at 75,50 , and $25 \%$ of FVC $\left(\mathrm{MEF}_{75}, \mathrm{MEF}_{50}, \mathrm{MEF}_{25}\right)$. The $\mathrm{MEF}_{50} / \mathrm{MEF}$ ratio, which seems to be equivalent to the $\beta$ of Kapp et al, ${ }^{12}$ was also calculated to obtain information about the morphology of the curve.

\section{POPULATIONS ANALYSED}

Questionnaires were offered to 108 workers exposed to MMA in four factories and 105 controls engaged in similar job categories but without exposure to MMA. The response rate was $81.48 \%$ and $87 \cdot 61 \%$ respectively. After processing questionnaire data, it was noted that the two groups were not comparable with regard to occupational history. In particular, there were more ex-miners and other workers previously exposed to dust (particularly fertiliser dusts) in the control group than in the exposed group. As bronchial hyper-reactivity is more often found in coal miners, ${ }^{13}$ variations in spirographic variables across the shift may be more intensive than in other workers. Similarly, respira-
Table 1 Anthropometric data and smoking habits among exposed workers $v$ controls

\begin{tabular}{llll}
\hline & $\begin{array}{l}\text { Control } \\
\text { group }\end{array}$ & $\begin{array}{l}\text { Exposed } \\
\text { group }\end{array}$ & $\begin{array}{l}\text { Statistical } \\
\text { significance }\end{array}$ \\
\hline Age (y) & $39(6)$ & $37(7)$ & NS \\
Weight (kg) & $78(13)$ & $75(10)$ & NS \\
Height (cm) & $174(7)$ & $173(7)$ & NS \\
Tobacco (pack-years) & $16(11)$ & $13(11)$ & NS \\
Non-smokers & $20(44 \cdot 5 \%)$ & $13(32 \cdot 5 \%)$ & NS \\
Ex-smokers & $7(15 \cdot 5 \%)$ & $11(27 \cdot 5 \%)$ & NS \\
Smokers & $18(40 \%)$ & $16(40 \%)$ & NS \\
\hline
\end{tabular}

tory function disorders have been described in workers exposed to fertiliser dusts. ${ }^{14}$ Consequently, the following persons were excluded from the study: 81 workers whose occupational history included work in coal mines or exposure to fertiliser dust and 14 persons exposed to MMA for less than five years who worked in two factories where the mean concentration of MMA was very low $(2 \cdot 7$, and $0.7 \mathrm{ppm})$. Thus the study population was composed of eight workers with more than five but less than 10 years exposure and 32 workers with more than 10 years exposure. They worked in two factories where the mean atmospheric concentrations of MMA were 18.5 and $21.6 \mathrm{ppm}$ with ranges of $9-32$ and 11.9 to $38.5 \mathrm{ppm}$. Table 1 shows the anthropometric data and smoking habits of 40 exposed workers and 45 controls.

\section{PROTOCOL}

Questionnaires were administered by the same trained interviewer, followed by a training session in spirography, to avoid an eventual learning effect. ${ }^{15}$ One or two days later, two respiratory measurements were performed, one before the shift and the second in the last two hours of the eight hour shift. To avoid circadian variations, ${ }^{16-19}$ investigations were always done in afternoon workshifts.

\section{STATISTICAL ANALYSIS}

Data were coded and computer assisted analyses were performed. Spirometric values before the workshift were expressed as ratios of observed/ predicted values. The predicted values were given by Knudson et al. ${ }^{20} 21$ Variations between the beginning and the end of the workshift were also expressed as ratios of after and before workshift values. As stated previously, our study was performed on 40 workers exposed exclusively to MMA for at least five years and on a comparable control group of workers never exposed to MMA or any other respiratory irritant. Analysis in this study employed the Student's $t$ test for comparing two means and a $\chi^{2}$ analysis of contingency tables for comparison of qualitative variables. When cells had numbers less than five, Fisher's exact test was used. To study the effects of tobacco, we used a two way variance 
Table 2 Chest symptoms among exposed workers and controls

\begin{tabular}{|c|c|c|c|}
\hline & $\begin{array}{l}\text { Control } \\
\text { group } \\
\text { No }(\%)\end{array}$ & $\begin{array}{l}\text { Exposed } \\
\text { group } \\
\text { No }(\%)\end{array}$ & $\begin{array}{l}\text { Statistical } \\
\text { significance }\end{array}$ \\
\hline Morning cough & $6(13)$ & $10(25)$ & NS \\
\hline Chronic cough & $2(<1)$ & $8(20)$ & $p=0.04$ \\
\hline $\begin{array}{l}\text { Morning sputum } \\
\text { production }\end{array}$ & $5(11)$ & $6(15)$ & NS \\
\hline $\begin{array}{l}\text { Chronic sputum } \\
\text { production }\end{array}$ & 1 & $4(10)$ & NS \\
\hline Dyspnoea & $8(18)$ & $15(37)$ & NS \\
\hline Wheezing & $5(11)$ & $5(12)$ & NS \\
\hline Asthma & 0 & 0 & NS \\
\hline Previous bronchitis & $17(38)$ & $19(48)$ & NS \\
\hline
\end{tabular}

analysis with the SAS general linear models procedure. The $\chi^{2}$ test (Mantel-Haenszel) was also used for testing the influence of smoking on chronic cough.

\section{Results}

Table 1 shows anthropometric data and smoking habits. There was no significant difference in age, weight, and height between exposed and control workers. Cigarette smoking was also similar. There were no pipe or cigar smokers. Table 2 shows the chest symptoms. Functional signs were more frequent in the exposed group but the difference was significant only for chronic cough $(p=0.04)$. This difference remained significant after adjustment for smoking $\left(\chi^{2}=4 \cdot 75, p=0 \cdot 03\right)$. Table 3 shows the frequency distribution of chronic cough in respect of smoking and exposure to MMA. Thus tobacco consumption was not a confounding factor and cannot solely explain the difference between exposed and control workers.

Spirometric values before the shift did not differ between control and exposed groups. There was no significant difference shown in observed/predicted ratios (table 4). With regard to functional changes within the workshift, all variables (except $\mathrm{MEF}_{75}$ ) decreased (table 5 ). This could be explained by circadian variations, but the decrease was higher in

Table 4 Spirometric variables for exposed group and controls

\begin{tabular}{llll}
\hline & $\begin{array}{l}\text { Control } \\
\text { group } \\
(n=45)\end{array}$ & $\begin{array}{l}\text { Exposed } \\
\text { group } \\
(n=40)\end{array}$ & $\begin{array}{l}\text { Statistical } \\
\text { significance }\end{array}$ \\
\hline FVC & $1.01(0.17)$ & $1.02(0.12)$ & NS \\
FEV $_{1}$ & $1.00(0.17)$ & $1.01(0.15)$ & NS \\
$\mathrm{FEV}_{1} /$ FVC & $0.98(0.01)$ & $0.98(0.07)$ & NS \\
$\mathrm{MEF}^{\mathrm{MEF}}$ & $1.03(0.18)$ & $1.05(0.2)$ & NS \\
$\mathrm{MEF}_{75}$ & $0.95(0.27)$ & $0.98(0.35)$ & NS \\
$\mathrm{MEF}_{50}$ & $1.03(0.23)$ & $1.05(0.22)$ & NS \\
$\mathrm{MEF}_{25}$ & $1.06(0.3)$ & $1.08(0.42)$ & NS \\
$\mathrm{MEF}_{50} / \mathrm{MEF}$ & $0.85(0.33)$ & $0.91(0.38)$ & NS \\
\hline
\end{tabular}

Figures are observed values before shift/predicted values (SD).
Table 3 Frequency distribution of chronic cough in respect of smoking and exposure to $M M A$

\begin{tabular}{lll}
\hline & $\begin{array}{l}\text { No cough } \\
\text { No (\%) }\end{array}$ & $\begin{array}{l}\text { Cough } \\
\text { No (\%) }\end{array}$ \\
\hline $\begin{array}{lll}\text { Non-smokers: } \\
\quad \text { Controls }\end{array}$ & $19(57 \cdot 58)$ & $1(3 \cdot 03)$ \\
$\begin{array}{l}\text { Exposed } \\
\text { Ex-smokers: }\end{array}$ & $11(33 \cdot 33)$ & $2(6 \cdot 06)$ \\
$\quad \begin{array}{l}\text { Controls } \\
\text { Exposed }\end{array}$ & $7(38 \cdot 89)$ & $0(0)$ \\
$\begin{array}{c}\text { Smokers: } \\
\text { Controls }\end{array}$ & $9(50)$ & $2(11 \cdot 11)$ \\
Exposed & $17(50)$ & $1(2 \cdot 94)$ \\
\hline
\end{tabular}

the group of exposed workers than in controls. The difference for after shift/before shift ratios was significant for $\mathrm{MEF}_{50}$ and $\mathrm{MEF}_{50} / \mathrm{MEF}(\mathrm{p}=0.04$ and 0.01 respectively). Other ratios decreased but not significantly. The variance analysis with regard to the after shift/before shift ratios of $\mathrm{MEF}_{50}$ and $\mathrm{MEF}_{50} / \mathrm{MEF}$ supports the hypothesis that MMA is exclusively responsible for the decrease in the variables considered (tables 6 and 7 respectively).

\section{Discussion and conclusion}

This study showed an increase in the prevalence of chronic cough in a group of workers exposed to MMA. In the same group, airway resistance increased during an eight hour workshift of workers exposed to MMA for at least five years. This obstruction was mild, and $\mathrm{FEV}_{1}$ did not decrease during the workshift. As in France workers are medically examined at least once every year, however, and in case of health problems the occupational physician can recommend transfer to other job; it may be that without such a transfer the respiratory effects of MMA would have been more severe and widespread. From a methodological point of view, the after shift/before shift ratios of $\mathrm{MEF}_{50}$ and $\mathrm{MEF}_{50} / \mathrm{MEF}$ seem to be useful on a group level, for the detection of mild airways obstruction caused by exposure to an irritant substance such as MMA. Our results support the

Table 5 Spirometric variables for exposed group and controls

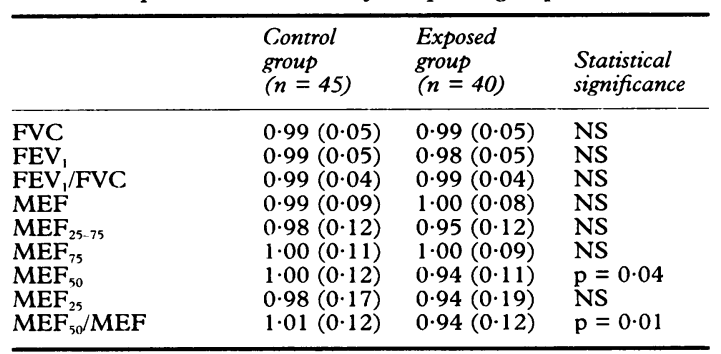

Figures are observed values after workshift/observed values before a workshift (SD). 
Table 6 Analysis of variance concerning the $M E F_{50}$ (after shift/before shift values)

\begin{tabular}{|c|c|c|}
\hline & \multicolumn{2}{|l|}{$M E F_{50}$ ratio } \\
\hline & $\begin{array}{l}\text { Controls } \\
\text { Mean (SD) }\end{array}$ & $\begin{array}{l}\text { Exposed } \\
\text { Mean (SD) }\end{array}$ \\
\hline Non-smokers & $\begin{array}{l}1 \cdot 00(0 \cdot 14) \\
(\mathrm{n}=20)\end{array}$ & $\begin{array}{l}0.97(0 \cdot 10) \\
(n=13)\end{array}$ \\
\hline Ex-Smokers & $\begin{array}{l}1 \cdot 02(0 \cdot 10) \\
(\mathrm{n}=7)\end{array}$ & $\begin{array}{l}0.94(0.13) \\
(n=11)\end{array}$ \\
\hline Smokers & $\begin{array}{l}1 \cdot 00(0 \cdot 10) \\
(n=18)\end{array}$ & $\begin{array}{l}0.95(0.11) \\
(n=16)\end{array}$ \\
\hline $\begin{array}{l}\text { F Value: } \\
\text { MMA } \\
\text { Tobacco } \\
\text { MMA + Tobacco }\end{array}$ & $\begin{array}{l}4 \cdot 16 \\
0 \cdot 1 \\
0 \cdot 29\end{array}$ & $\begin{array}{l}p=0.044 \\
p=0.908 \\
p=0.75\end{array}$ \\
\hline
\end{tabular}

hypothesis that MMA can be responsible for pulmonary functional disorders ${ }^{6}$ and for airway obstruction $^{8}$ among occupationally exposed workers. Differences between exposed and control groups remained after adjustment for smoking habits. There was no interaction between MMA and smoking ( $p>0.05$ for both variables). A further prospective survey on larger population samples would be of great interest because such a study could include those who move to other jobs because of respiratory disorders.

We are grateful to Drs Kaczmarek, Simon, Mery, and Galeau for their help and cooperation in these investigations. We are deeply indebted to Mrs Jeannie Josey-Taillat for her help in the revision of the manuscript.

1 McLaughlin RE, Difazio CA, Hakala M, Abbott B, Macphail JA, Mack WP, Sweet DE. Blood clearance and acute pulmonary toxicity of methylmethacrylate in dogs after simulated arthroplasty and intravenous injection. $f$ Bone foint Surg (Am) 1973;60A:355-8.

2 Kessler MJ, Kupper JL, Brown RJ. Accidental methylmethacrylate inhalation toxicity in a Rhesus Monkey (Macaca Mulatta). Lab Anim Sci 1977; 27:388-90.

3 Holland CJ, Kim KC, Malik MI, Ritter MA. Histologic and hemodynamic study of the toxic effects of monomeric methylmethacrylate. Clin Orthop 1973;90:262-70.

4 Raje RR, Ahmad S, Weisbroth SH. Methylmethacrylate: Tissue distribution and pulmonary damage in rats following acute inhalation. Res Commun Chem Pathol Pharmacol 1985; 50:151-4.

5 Blanchet LJ, Bowman DC, McReynolds HD. Effects of methylmethacrylate monomer vapors on respiration and circulation in unanesthetized rats. F Prosthet Dent 1982;48: 344-8.

6 Karpov BD. Methylmethacrylate from the viewpoint of labor hygiene. Gig Sanit 1954;1:25-8.
Table 7 Analysis of variance concerning the $M E F_{50} / M E F$ ratio (after shift/before shift values)

\begin{tabular}{lll}
\hline & \multicolumn{2}{l}{$M E F_{50} / M E F$ ratio } \\
\cline { 2 - 3 } & $\begin{array}{l}\text { Controls } \\
\text { Mean }(S D)\end{array}$ & $\begin{array}{l}\text { Exposed } \\
\text { Mean }(S D)\end{array}$ \\
\hline Non-smokers & $\begin{array}{l}1.01(0.11) \\
(\mathrm{n}=20)\end{array}$ & $\begin{array}{l}0.96(0.08) \\
(\mathrm{n}=13)\end{array}$ \\
Ex-smokers & $\begin{array}{l}1.08(0 \cdot 16) \\
(\mathrm{n}=7)\end{array}$ & $\begin{array}{l}0.94(0.15) \\
(\mathrm{n}=11)\end{array}$ \\
Smokers & $\begin{array}{l}0.99(0.12) \\
(\mathrm{n}=18)\end{array}$ & $\begin{array}{l}0.94(0.14) \\
(\mathrm{n}=16)\end{array}$ \\
F Value & $\begin{array}{l}0.18 \\
\text { MMA }\end{array}$ & $\mathrm{p}=0.015$ \\
Tobacco & 0.57 & $\mathrm{p}=0.568$ \\
MMA + Tobacco & 0.84 & $\mathrm{p}=0.437$ \\
\hline
\end{tabular}

7 Kennes B, Garcia-Herreros P, Diercks P. Asthma from plexiglas powders. Clin Allergy 1981;11:49-54.

8 Jedrykowski $\mathrm{W}$. Styrene and methylmethacrylate in the industrial environment as a risk factor of chronic obstructive lung disease. Int Arch Occup Environ Health 1982;51:151-7.

9 World Health Organisation. Epidemiology of chronic non specific respiratory disease. Bull World Health Organ 1975; 52:251-60.

10 American Thoracic Society. ATS statement: Snowbird workshop on standardization of spirometry. Am Rev Respir Dis 1979;119:831-8.

11 American Thoracic Society. Standardization of spirometry. Update. Am Rev Respir Dis 1987;136:1285-98.

12 Kapp MC, Schachter EN, Beck GJ, Maunder LR, Witek TJ. The shape of maximum expiratory flow volume curve. Chest 1988;94:799-806.

13 Guerrin F, Robin H, Boulenguez C. Paramètres respiratoires chez les mineurs pneumoconiotiques du bassin houiller du Nord-Pas de Calais. Bulletin Europeén de Physiopathologie Respiratoire 1975;11:569-88.

14 Lehnigk B, Thiele E, Wosnitza $\mathrm{H}$. Respiratory function disorders caused by agrochemical exposure. Z Erkr Atmungsorgane $1985 ; 164: 267-9$.

15 Guberan E, Williams MK, Walford J, Smith MM. Circadian variation of FEV on shift workers. Br $\mathcal{F}$ Ind Med 1969; 26:121-5.

16 Boehlecke BA, Merchant JA. The use of pulmonary function testing and questionnaires as epidemiologic tools in the study of occupational lung disease. Chest 1981;79:114-21.

17 Nemery B, Vanleelmpupptten R, Goemare E, Veriter C, Brasseur L. Lung function measurements over 21 days shiftwork in steelworkers from a strandcasting department. $\mathrm{Br} \mathcal{F}$ Ind Med 1985;42:601-11.

18 Edmé JL, Thuillier JC, Boulenguez C, Robin H, Frimat $P$, Furon D. Enquête respiratoire chez des teilleurs de lin: résultats fonctionnels respiratoires. Archives des Maladies Professionnelles 1988;49:103-5.

19 Boulenguez C, Pila C, Edmé JL, Hubert C, Robin H, Frimat $P$. Enquête respiratoire dans une filature de coton: historique et premiers résultats. Cahiers de Médecine du travail 1989;26:65-72.

20 Knudson RJ, Slatin RC, Lebowitz MD, Burrows B. The maximal expiratory flow volume curve: Normal standards, variability and effects of age. Am Rev Respir Dis 1976;113: 587-600.

21 Knudson RJ, Lebowitz MD, Holberg CI, Burrows B. Changes in the normal maximum expiratory flow volume curve with growth and aging. Am Rev Respir Dis 1983;127:725-34.

Accepted 14 December 1992 